\title{
Body lipid deposition in Nile tilapia fed on rations containing tannin
}

\author{
Felipe Shindy Aiura(1) and Maria Regina Barbieri de Carvalho(1)
}

\begin{abstract}
(1)Universidade Estadual Paulista, Fac. de Ciências Agrárias e Veterinárias, Dep. de Tecnologia, Via de Accesso Prof. Paulo Donato Castellane, s/no, CEP 14884-900 Jaboticabal, SP, Brazil. E-mail: felipe-aiura@ig.com.br, mrbcar@fcav.unesp.br
\end{abstract}

\begin{abstract}
The aim of this work was to evaluate the effect of tannin sources and levels in rations, on the productive performance and body lipid deposition of Nile tilapias (Oreochromis niloticus) during the finishing phase. Three hundred and forty-two fishes were distributed in 18 tanks. Rations were prepared using corn, sorghum varieties, with low and high tannin content, and tannic acid at $0.08,0.34$, and $0.60 \%$. Weight gain, apparent feed conversion and protein efficiency rate were not influenced by the treatments. The highest body lipid deposition was observed for the tannic acid treatment $(14.39 \%)$, while the diet containing sorghum with high tannin content yielded leaner body $(12.01 \%)$ than that of sorghum with low tannin content (13.31\%). Diets containing sorghum provided lower levels of visceral fat. Rations with tannin contents did not harm the productive performance of Nile tilapia.
\end{abstract}

Index terms: Oreochromis niloticus, tannic acid, body fat, sorghum.

\section{Deposição lipídica corporal em tilápia-do-nilo alimentada com rações com tanino}

Resumo - O objetivo deste trabalho foi avaliar o efeito de fontes e níveis de tanino em rações para tilápia-do-nilo (Oreochromis niloticus), durante a engorda, sobre o desempenho produtivo e deposição lipídica corporal. Foram utilizados 342 peixes, distribuídos em 18 tanques. As rações foram preparadas com milho, variedades de sorgo com baixo e alto teor de tanino, e com ácido tânico a 0,08, 0,34, e 0,60\%. Ganho de peso, conversão alimentar aparente e taxa de eficiência protéica não foram influenciados pelos tratamentos. A maior deposição lipídica corporal foi observada nas dietas com ácido tânico (14,39\%); a dieta de sorgo com alto teor de tanino resultou em carcaças mais magras $(12,01 \%)$ do que as de sorgo com baixo teor de tanino (13,31\%). Dietas com sorgo proporcionaram menores teores de gordura visceral. A presença de tanino nas rações não prejudicou o desempenho produtivo da tilápia-do-nilo.

Termos para indexação: Oreochromis niloticus, ácido tânico, gordura corporal, sorgo.

\section{Introduction}

Tannins are water soluble compounds that can be found in many superior plants. They can be classified as hydrolyzable and condensed due to their chemical structure. Tannins are able of reacting with proteins, digestive enzymes, polysaccharides and other molecules, reducing digestibility of the amino acids of the diet.

Condensed tannins have been reported as responsible for the inhibition of the enzymatic activity of the celulase, pectinase, amylase, lipase, proteolytic enzymes and the alpha-galactosidase (Chung et al., 1998). For these reasons, their presence in foods has harmful effects on animal health and development, as well as causes decrease in food palatability, voluntary intake proteins, carbohydrates, starch, lipid digestibility and depletion of calcium absorption (Chang et al., 1994).
Castro et al. (1998) evaluated the inclusion of levels between 20 and $40 \%$ sorghum in growth rations for red tilapia (Oreochromis spp.), and observed that the maximum level of inclusion did not impair weight gain of the fish.

The effects of $2 \%$ tannic acid (hydrolyzable tannin), and $2 \%$ condensed tannin from quebracho (Loxopterigium loetzil) on common carp (Cyprinus carpio L.) performance were evaluated by Becker \& Makkar (1999), who observed that, after 84 days, the condensed tannin did not affect food intake, weight gain and body composition. However, tannic acid yielded adverse effects after the $28^{\text {th }}$ day, and complete rejection to the diet occurred after 40 days.

The effect of tannin of Dimorphandra mollis Benth on the apparent digestibility of the diet for Nile tilapia (Oreochromis niloticus) was evaluated by Pinto et al. (2000). 
The results indicated that levels equal or superior to $0.63 \%$ affected significantly the digestibility of dry matter, crude protein and ether extract.

The "piauçu" (Leporinus macrocephalus) fingerlings fed on diets containing different tannin levels had their performance evaluated by Pinto et al. (2001). After 60 days, the "piauçu" showed sensitiveness to condensed tannins, which significantly damaged the metabolism and the biological value of the nutrients present in the rations.

For these reasons, limits are set to the utilization of ingredients containing tannins, in order to not impair animal productive performance. Benefit and potential effects of the tannins, such as antimicrobial and antioxidants properties, are reported to be useful in the processing of food rations. They also have physiologic effects - such as accelerating blood clotting, and reducing lipid and blood cholesterol levels - and ability to act as anticarcinogenic (Chung et al., 1998). Experiments utilizing several alimentary sources containing tannin, in the feed of some species of fish, demonstrated low lipid deposit in the carcasses and viscera (Hossain at al., 2001a, 2001b).

The hypocholesterolemic effect of the tannins was attributed to the antioxidant action, which blocks the initiation and propagation of free radicals that induce to the oxidation of the LDL cholesterol (Auger et al., 2002; Weisbuger \& Chung, 2002). Another effect is associated to the inhibition of 3-hydroxy-3-methylglutaril CoA reductase, enzyme necessary to the cholesterol biosynthesis (Chang, 2001). The plasmatic cholesterol levels were reduced $40 \%$ by the inclusion of $24 \%$ of sesbania (Sesbania aculleata) seed meal in diets for carp, compared to diets without tannin (Hossain et al., 2001b).

Pinto et al. (2001) observed an increase in fat excretion, in the feces, as well as a lower lipid deposit in the carcass, viscera and liver in "piauçu", after using low condensed tannin levels in rations.

The aim of this work was to evaluate the effect of tannin sources and levels in rations, on the performance and body composition of Nile tilapia during the finishing phase.

\section{Material and Methods}

The experiment was carried out at the Centro Nacional de Pesquisa de Peixes Tropicais - CEPTA/IBAMA, Pirassununga, SP, Brazil, from February to May, 2002, and lasted 90 days. The experimental design was a completely randomized design, with six treatments and three replicates. Three hundred and forty-two fishes of Nile tilapia were utilized, with average weight of $120 \pm 10 \mathrm{~g}$. Fishes were distributed in 18 experimental units, consisting of $4 \mathrm{~m}^{3}$ tanks with a discharge of $33 \mathrm{~L}$ per minute. Each experimental unit received 19 fishes.

The rations were prepared using corn, soybean meal, wheat meal, fish flour, mineral and vitamin "Supremais" supplement. The six treatments consisted of high and low tannin (condensed tannin) content of sorghum varieties and tannic acid (hydrolyzable tannin) at 0.08 , 0.34 and $0.60 \%$. Sorghum treatment totally substituted the one with corn; and tannic acid levels approached the amount of tannin supplied by the sorghum variety with tannin levels $0.087 \%$ (low), $0.57 \%$ (high) and $0.34 \%$ (intermediary) used to compare treatments. Rations were prepared every 20 days; the ingredients were grounded, mixed, forming a moist pellet of about $4 \mathrm{~mm}$ in diameter (Table 1). The energy and the digestible protein of the rations were calculated on the basis of the values obtained by Boscolo et al. (2002), Pezzato et al. (2002) and Freire (2004).

Fishes were fed ad libitum four times a day. Data of food intake were registered daily. Fishes were weighed in the beginning and in the end of the experimental period. Water temperature and dissolved oxygen were determined daily by an YSI model 57 digital measurer, and $\mathrm{pH}$ was measured weekly by Fisher model 119 equipment.

At the end of the experiment, all fishes were weighed; six fishes of each tank died of thermal shock and were stored in a freezer to be analyzed later. Five fishes of each tank were separated for withdrawal of blood through puncture in the vein stream; their abdominal cavity was opened to draw off the liver and visceral fat, which were weighed; the liver was frozen for later analysis.

Weight gain (final minus initial weight), apparent feed conversion (feed intake/weight gain), proteic efficiency rate (weight gain/protein intake), crude protein of the body, body total lipid, visceral fat, total lipid in the liver, hepatossomatic index [(liver weight x 100)/body weight], blood triglycerides, and cholesterol were analyzed.

The analysis of crude protein followed the methods of the Association of Official Analytical Chemists (AOAC, 1995). The extraction of liver and body total lipid was accomplished according to Bligh \& Dyer (1959). Triglycerides and cholesterol were quantified by Cat. 59 and Cat. 60, Labtest Diagnostic's kits, 
respectively. Tannin levels in sorghum were measured by vanillin $-\mathrm{HCl}$ method (Price et al., 1978).

Data were submitted to variance analysis through SAS software (SAS Institute, 1995). The F test for orthogonal contrasts was utilized for the treatments. Significance of observed differences was tested at $\mathrm{p}<0.05$.

\section{Results and Discussion}

Water parameters were maintained within comfortable levels for tilapia, according to Boyd (1990). Temperature between 26 and $30^{\circ} \mathrm{C}, \mathrm{DO}_{2}$ between 5.2 and $6.0 \mathrm{mg} \mathrm{L}^{-1}$, and average $\mathrm{pH}$ of 6.5 were registered.

Mean values for productive parameters did not present significant effects by $\mathrm{F}$ test. Results for weight gain indicated that sorghum can be used as an alternative ingredient in rations for Nile tilapia (Table 2).

Castro et al. (1998) also used diets with sorghum for tilapia, and concluded that the inclusion of $40 \%$ of this ingredient resulted in better weight gain than the utilization of a commercial ration. Freire (2002) studied tilapia fry and found no significant differences for weight gain, between the treatment with corn and the ones with sorghum, for rations containing sorghum varieties with high and low tannin, and with and without methionine supplementation.

Results for weight gain, obtained in the present work, with the tannic acid levels 0.34 and $0.60 \%$, may be due to a lesser acceptance of the food, in the last days of the experimental phase.

Al-Owafeir (1999) observed no decrease in the growth of Nile tilapia fed on ration containing $0.27 \%$ tannic acid. Becker \& Makkar (1999), however, recommended caution in the use of rations containing tannic acid due to its high toxicity to fishes.

Mean values found for feed conversion could make the cultivation unfeasible. These results can be related to the alimentary regime adopted, as well as to the type of rations utilized, which might have caused food waste. Similar results were found by Castro et al. (1998). However, Freire (2002) observed worse feed conversion rates in tilapia fed on diets containing sorghum with high tannin (condensed).

Pinto et al. (2001) utilized different condensed tannin levels in food for fry of "piauçu", and verified that rates of tannin up to $0.69 \%$ did not damage significantly the apparent feed conversion. In a study utilizing diets containing tannin rates from 0.27 to $1.08 \%$, for common

Table 1. Ingredients and composition of the rations for control, low tannin sorghum (LTS), high tannin sorghum (HTS), tannic acid $0.08 \%$ (TA-0.08), tannic acid $0.34 \%$ (TA-0.34) and tannic acid $0.60 \%$ (TA-0.60) treatments.

\begin{tabular}{lcccccc}
\hline Ingredient & \multicolumn{2}{c}{ Treatment } & & \\
\cline { 2 - 6 } & Control & LTS & HTS & TA-0.08 & TA-0.34 & TA-0.60 \\
\hline Tannic acid & - & - & - & 0.08 & 0.34 & 0.60 \\
Corn & 30 & - & - & 30 & 30 & 30 \\
Sorghum & - & 30 & 30 & - & - & - \\
Wheat meal & 4.4 & 4.9 & 4.9 & 4.32 & 4.06 & 3.8 \\
Soybean meal & 51.5 & 52.0 & 52.0 & 51.5 & 51.5 & 51.5 \\
Fish meal & 10 & 9 & 9 & 10 & 10 & 10 \\
Soybean oil & 3.5 & 3.5 & 3.5 & 3.5 & 3.5 & 3.5 \\
Supremais & 0.6 & 0.6 & 0.6 & 0.6 & 0.6 & 0.6 \\
\hline Total (\%) & 100 & 100 & 100 & 100 & 100 & 100 \\
Composition & & & & & & \\
Digestible protein (\%) & 28.6 & 28.9 & 28.6 & 28.6 & 28.6 & 28.5 \\
Digestible energy (kcal kg-1) & 3,246 & 3,166 & 3,078 & 3,244 & 3,236 & 3.228 \\
Ether extract & 6.48 & 6.44 & 6.44 & 6.48 & 6.47 & 6.46 \\
Crude fiber & 4.44 & 4.56 & 4.56 & 4.43 & 4.40 & 4.38 \\
Lysine & 2.14 & 2.08 & 2.08 & 2.14 & 2.13 & 2.13 \\
Methionine & 0.61 & 0.58 & 0.58 & 0.61 & 0.61 & 0.61 \\
Calcium & 0.79 & 0.72 & 0.72 & 0.79 & 0.79 & 0.79 \\
Available phosphorous & 0.73 & 0.65 & 0.65 & 0.72 & 0.72 & 0.72 \\
Hydrolyzable tannin & - & - & - & 0.08 & 0.34 & - \\
Condensed tannins & - & 0.087 & 0.57 & - & - & - \\
\hline
\end{tabular}

${ }^{(1)}$ Mineral and vitamin supplement (ingredients per kg): A: 1,200,000 UI; $\mathrm{D}_{3}: 200,000 \mathrm{UI} ; \mathrm{E}: 12,000 \mathrm{mg} ; \mathrm{K}_{3}: 2,400 \mathrm{mg} ; \mathrm{B}_{1}: 4,800 \mathrm{mg} ; \mathrm{B}_{2}: 4,800 \mathrm{mg}$; $\mathrm{B}_{6}: 4,000 \mathrm{mg} ; \mathrm{B}_{12}: 4,800 \mathrm{mg}$; folic acid: 1,200 mg; Ca pantotenate: 12,000 mg; C: 48,000 mg; biotin: $48 \mathrm{mg}$; colin: $65,000 \mathrm{mg} ;$ niacin: $24,000 \mathrm{mg}$; Fe: 10,000 mg; Cu: $600 \mathrm{mg}$; Mn: 4,000 mg; Zn: 6,000 mg; I: $20 \mathrm{mg}$; Co: $2 \mathrm{mg}$; and Se: $20 \mathrm{mg}$. 
carp, Hossain et al. (2001a) observed worse feed conversion index, in diets with rates starting at $0.54 \%$ of tannin.

Castro et al. (1998) verified no significant differences for proteic efficiency rate, when diets containing 20 and $40 \%$ sorghum for Nile tilapia were used in comparison with a commercial diet. Pinto et al. (2001) utilizing condensed tannin levels, among 0.23 and $1.82 \%$, in diets for "piauçu", observed that the proteic efficiency rate was harmed, starting at $0.92 \%$ tannin in the diet, a level above the utilized in this work, which may confirm the antinutritional action of this substance.

Table 2. Average values of weight gain (WG), apparent feed conversion (AFC) and protein efficiency rate (PER) for Nile tilapia fed on diets containing sorghum varieties with low and high tannin content and tannic acid levels, and $\mathrm{F}$ test values for the interactions.

\begin{tabular}{lccc}
\hline Variation source & & \\
\hline Control & WG $(\mathrm{g})$ & AFC & PER \\
LTS & 287 & 2.20 & 1.42 \\
HTS & 263 & 2.43 & 1.29 \\
TA-0.08\% & 279 & 2.30 & 1.37 \\
TA-0.34\% & 261 & 2.46 & 1.27 \\
TA-0.60\% & 252 & 2.36 & 1.33 \\
\hline F test & 254 & 2.35 & 1.33 \\
Control x other treatments & 1.71 & 0.96 & 1.08 \\
Sorghum x TA & 4.51 & 3.03 & 3.40 \\
LTS x HTS & 1.11 & 0.89 & 1.15 \\
TA (linear effect) & 0.17 & 0.68 & 0.57 \\
CV $(\%)$ & 0.20 & 0.15 & 0.12 \\
\hline
\end{tabular}

${ }^{(1)}$ LTS: low tannin sorghum content; HTS: high tannin sorghum content; TA-0.08: tannic acid $0.08 \%$; TA-0.34: tannic acid $0.34 \%$; TA-0.60: tannic acid $0.60 \%$.
No significant difference was observed for liver total lipid, hepatossomatic index and total cholesterol. Significant difference was observed for crude protein, body total lipid, visceral fat and triglycerides, for fish in the different treatments (Table 3).

The analysis showed that the control treatment presented the lowest concentration of crude protein in the body, and differed significantly from the other treatments. Diets containing tannin provided high protein levels, and significant interaction $(\mathrm{p}<0.05)$ between sorghum varieties and tannic acid levels was observed; moreover, diets containing tannic acid presented great proteic deposition in the body.

Pinto et al. (2001) also observed increase in the protein level of "piauçu" carcasses due to tannin level in the ration, showing linear growth with the coefficient of correlation equal to $82 \%$.

Carps fed during 84 days presented no significant differences for protein of the carcass, when the diet contained $2 \%$ condensed tannin of quebracho (Becker \& Makkar, 1999). Authors concluded that this species seems not to suffer the action of condensed tannin, due to the process of alkaline digestion, which can avoid connections between tannins and proteins and does not interfere in the digestibility and metabolism of this nutrient.

For values of total lipid in the body, among tannin sources used, the highest lipid deposition was observed for the tannic acid treatments, differing significantly from other rations containing sorghum. Sorghum varieties showed that fishes fed on the diet with high tannin had leaner body than the ones fed on low tannin.

Table 3. Average values of crude protein of the body (CPB), total lipid of the body (TLB), visceral fat (VF), total lipid in the liver (TLL), hepatossomatic index (HSI), triglycerides (TG) and total cholesterol (TC), in Nile tilapia fed on diets containing sorghum varieties with low and high tannin content and tannic acid levels, and $\mathrm{F}$ test values for the interactions.

\begin{tabular}{|c|c|c|c|c|c|c|c|}
\hline Variation sources $^{(1)}$ & $\begin{array}{c}\text { CPB } \\
(\%)\end{array}$ & $\begin{array}{l}\text { TLB } \\
(\%)\end{array}$ & $\begin{array}{l}\text { VF } \\
(\%)\end{array}$ & $\begin{array}{l}\text { TLL } \\
(\%)\end{array}$ & HSI & $\begin{array}{c}\mathrm{TG} \\
\left(\mathrm{mg} \mathrm{dL}^{-1}\right)\end{array}$ & $\begin{array}{c}\mathrm{TC} \\
\left(\mathrm{mg} \mathrm{dL}^{-1}\right)\end{array}$ \\
\hline Control & 15.91 & 12.28 & 3.90 & 5.92 & 2.66 & 417.32 & 133.98 \\
\hline LTS & 16.51 & 13.31 & 3.68 & 5.44 & 2.76 & 283.78 & 115.08 \\
\hline HTS & 16.98 & 12.01 & 3.12 & 5.64 & 2.53 & 237.84 & 110.16 \\
\hline TA $-0.08 \%$ & 17.14 & 14.36 & 5.27 & 6.63 & 2.56 & 431.08 & 125.29 \\
\hline TA-0.34\% & 17.26 & 14.24 & 4.74 & 6.39 & 2.48 & 314.28 & 133.04 \\
\hline TA- $-0.60 \%$ & 17.15 & 14.56 & 5.63 & 6.41 & 2.88 & 277.60 & 137.41 \\
\hline F test & $6.25^{*}$ & $18.61 *$ & $9.81 *$ & 2.21 & 2.08 & $5.48^{*}$ & 1.65 \\
\hline Control $\mathrm{x}$ other treatments & $23.14 *$ & $24.97 *$ & 2.98 & 0.13 & 0.02 & $8.54 *$ & 1.07 \\
\hline Sorghum x TA & $5.30 *$ & $54.39 *$ & $40.40^{*}$ & $10.55^{*}$ & 0.00 & $6.73 *$ & $6.02 *$ \\
\hline LTS x HTS & 2.59 & $12.92 *$ & 1.63 & 0.27 & 2.47 & 0.92 & 0.16 \\
\hline TA (linear effect) & 0.00 & 0.29 & 0.66 & 0.02 & $4.57^{*}$ & $10.27 *$ & 0.99 \\
\hline $\mathrm{CV}(\%)$ & 3.71 & 4.66 & 11.35 & 11.17 & 12.05 & 13.15 & 10.77 \\
\hline
\end{tabular}

(1)LTS: low tannin sorghum content; HTS: high tannin sorghum content; TA-0.08: tannic acid 0.08\%; TA-0.34: tannic acid 0.34\%; TA-0.60: tannic acid $0.60 \%$. * Significant at $5 \%$ probability level. 
The characteristic of the condensed tannin in forming complex with enzymes, as stated by Chung et al. (1998), seems to be one of the causes of lower lipid content in fish carcasses, damaging the use of the dietary lipid. However, the diets presented low variation in the digestible energy, which was lesser in the high tannin sorghum diet, and may have contributed to the lesser corporal lipid deposition.

Pinto et al. (2000) accomplished a digestibility essay with Nile tilapia, and also verified significant decrease of 96 to $92 \%$, in the digestibility coefficient of the diet lipid fraction, starting at the inclusion of $0.23 \%$ condensed tannin, which reinforced the hypothesis that enzymatic decrease was caused by tannins. A lower fat deposition in the body of fishes fed on condensed tannin was also observed by Hossain et al. (2001a) and Pinto et al (2001), related to the increase of the tannin level in the ration.

The comparison between treatments with sorghum and the ones with tannic acid demonstrated that tannin types influenced the visceral fat deposition, whose lowest values were observed in the treatments with sorghum. Pinto et al. (2001) observed decrease in the amount of visceral fat, with increase of the condensed tannin level in the "piauçu" diets.

Higher total lipid levels in the body, in the treatments containing tannic acid, may be due to larger amount of visceral fat, because tilapia does not utilize supplemental energy originating from lipid above $5 \%$ in the diet for its growth (Chou \& Shiau, 1996), which is deposited in the form of fat.

Total lipid levels in the liver of fishes were different for sorghum varieties (high and low tannin) and tannic acid levels $(0.08,0.34$, and $0.60 \%)$. Sorghum inclusion in the diets provided lower fat levels in the liver, probably due to low amount of digestible energy of the diet. Pinto et al. (2001) demonstrated that condensed tannin reduced fat deposition in the "piauçu" liver. However, tannic acid levels treatments provided larger lipid depositions in the liver.

The treatments caused no effects on the hepatossomatic index. Hossain et al. (2001b) observed no significant difference for the hepatossomatic index in carps fed on diets containing 0.24 to $0.55 \%$ of condensed tannin. In the treatments 0.08 and $0.60 \%$ tannic acid, the HSI was bigger than in the treatment $0.34 \%$ tannic acid. Those treatments had also bigger VF depositions in the liver.

Lipid accumulation in the liver may be due to blocking of the production of plasmatic lipoproteins, usually associated to methionine deficiency. As the tannic acid presents high similarity to methyl group, which damages the methionine available to the organism, the fat deposit in the hepatic tissue was favored. The main block of the mobilization of the hepatic fat in animals lacking lipotropic factors seems to be the incapacity of synthesis of the very low-density lipoproteins (VLDL) components, which are triglyceride carriers (Sgarbieri, 1987).

Triglycerides levels were influenced significantly by the diets. Fishes fed on the control diet presented greater amount of triglycerides than those fed on diets containing tannin: with $32 \%$ for sorghum low tannin, $43 \%$ for sorghum high tannin, $25 \%$ for tannic acid $0.34 \%$, and $33 \%$ for tannic acid $0.60 \%$. The inclusion of the lowest tannic acid level $(0.08 \%)$ led to significant interactions between sorghum varieties and tannic acid levels, and among tannic acid levels with 0.08 and $0.60 \%$.

Significant difference was observed for total cholesterol levels among the treatments. Among tannin sources, the condensed tannin from the sorghum led to lower cholesterol indexes than the hydrolyzable tannin. Hossain et al. (2001b) observed a reduction of $40 \%$ in the cholesterol level of the common carp fed on ration containing $0.5 \%$ of condensed tannin from sesbania seed.

The influence of sorghum in the concentration of total cholesterol may be related to the type of tannin present in the diet, since compounds belonging to the flavan-3-ol group, as the condensed tannin in the sorghum, are potent inhibitors of the HMG-CoA reductase, limiting enzyme in the cholesterol biosyntheses (Chang et al., 2001).

\section{Conclusion}

Tannin content in the rations does not damage the productive performance of the Nile tilapia; however, tannic acid (hydrolyzable tannin) provides greater corporal lipid deposition.

\section{References}

AL-OWAFEIR, M. The effects of dietary saponin and tannin on growth performance and digestion in Oreochromis niloticus and Clarias gariepinus. 1999. 220p. Thesis (Ph.D.) - University of Stirling, UK.

AOAC (Washington, Estados Unidos). Official methods of analysis. $16^{\text {th }}$ ed. Washington, 1995. 2v.

AUGER, C.; CAPORICCIO, B.; LANDRAULT, N.; TEISSEDRE, P.L.; LAURENT, C.; CROS, G.; BESANÇON, P.; ROUANET, J.M. 
Red wine phenolic compounds reduce plasma lipids and apolipoprotein B and prevent early aortic atherosclerosis in hypercholesterolemic golden syrian hamsters (Mesocricetus auratus). Journal of Nutrition, v.132, p.1207-1213, 2002.

BECKER, K.; MAKKAR, H.P.S. Effects of dietary tannic acid and quebracho tannin on growth performance and metabolic rates of common carp (Cyprinus carpio L.). Aquaculture, v.175, p.327$335,1999$.

BLIGH, E.G.; DYER, W.J. A rapid method of total lipid extraction and purification. Canadian Journal of Biochemistry and Physiology, v.37, p.911-917, 1959.

BOSCOLO, W.R.; HAYASHI, C.; MEURER, F. Digestibilidade aparente da energia e nutrientes de alimentos convencionais e alternativos para a tilápia-do-nilo (Oreochromis niloticus, L.). Revista Brasileira de Zootecnia, v.31, p.539-545, 2002.

BOYD, C.E. Water quality management for ponds fish culture: development in aquaculture and fisheries science. Amsterdan: Elsevier Scientific Publishing, 1990. 480p.

CASTRO, P.F.; CAVALTINI, L.B.; SILVA NETO, J.R.; CORREIA, E.S. Utilização de dietas à base de sorgo em rações de crescimento para a tilápia-vermelha (Oreochromis niloticus). In: AQUICULTURA BRASIL'98, 10., 1998, Recife. Proceedings. Recife: ABRAq, 1998. p.65-72.

CHANG, J.J.; CHEN, T.H.; CHAN, P.; CHEN, Y.J.; HSU, F.L.; LO, M.Y.; LIN, J.Y. The in vitro inhibitory effect of tannin derivatives on 3-hydroxy-3-methylglutaryl-coenzyme A reductase on Vero cells. Pharmacology, v.62, p.224-228, 2001.

CHANG, M.J.; BAILEY, J.W.; COLLINS, J.L. Dietary tannins from cowpeas and tea transiently alter apparent calcium absorption and utilisation of protein in rats. Journal of Nutrition, v.124, p.283288, 1994.

CHOU, B.S.; SHIAU, S.Y. Optimal dietary lipid level for growth of juvenile hybrid tilapia, Oreochromis niloticus x Oreochromis aureus. Aquaculture, v.143, p.185-195, 1996.

CHUNG, K.T.; WONG, T.Y.; WEI, C.I.; HUANG, Y.W.; LIN, Y. Tannins and human health: a review. Critical Reviews in Food Science and Nutrition, v.38, p.421-464, 1998.

FREIRE, E.D. Aminoácidos digestíveis do sorgo baixo e alto tanino e a substituição do milho pelo sorgo com base em proteína ideal para a tilápia-do-nilo (Oreochromis niloticus). 2004. 95p. Tese (Doutorado) - Universidade Estadual Paulista, Botucatu.

FREIRE, E.D. Avaliação biológica de sorgo alto e baixo tanino por meio do desempenho e digestibilidade em tilápia-do-nilo. 2002. 65p. Dissertação (Mestrado) - Universidade Estadual Paulista, Botucatu.

HOSSAIN, M.A.; FOCKEN, U.; BECKER, K. Effect of soaking and soaking followed by autoclaving of sesbania seeds on growth and feed utilisation in common carp, Cyprinus carpio L. Aquaculture, v.203, p.133-148, $2001 \mathrm{~b}$.

HOSSAIN, M.A.; FOCKEN, U.; BECKER, K. Evaluation of an unconventional legume seed, Sesbania aculeata, as a dietary protein source for common carp (Cyprinus carpio L.). Aquaculture, v.198, p.129-140, 2001a.

PEZZATO, L.E.; MIRANDA, E.C.; BARROS, M.M.; PINTO, L.G.Q.; FURUYA, W.M.; PEZZATO, A.C. Digestibilidade aparente de ingredientes pela tilápia-do-nilo (Oreochromis niloticus). Revista Brasileira de Zootecnia, v.31, p.1595-1604, 2002.

PINTO, L.G.Q.; PEZZATO, L.E.; MIRANDA, E.C.; BARROS, M.M. Desempenho do piauçu (Leporinus macrocephalus) arraçoado com dietas contendo diferentes níveis de tanino. Revista Brasileira de Zootecnia, v.30, p.1164-1171, 2001.

PINTO, L.G.Q.; PEZZATO, L.E.; MIRANDA, E.C.; BARROS, M.M.; FURUYA, W.M. Ação do tanino na digestibilidade de dietas pela tilápia-do-nilo (Oreochromis niloticus). Acta Scientiarum, v.22, p.677-681, 2000.

PRICE, M.L.; VAN SCOYOC, S.; BUTLER, L.G. A critical evaluation of the vanillin reaction as an assay for tannin in sorghum grain. Journal of Agricultural and Food Chemistry, v.26, p.12141218, 1978.

SAS INSTITUTE (Cary, Estados Unidos). SAS user's guide. Version 6. $4^{\text {th }}$ ed. Cary, 1995. 365p.

SGARBIERI, V.C. Alimentação e nutrição: fator de saúde e desenvolvimento. Campinas: Ed. da Unicamp, 1987. 387p.

WEISBURGER, J.H.; CHUNG, F.L. Mechanisms of chronic disease causation by nutritional factors and tobacco products and their prevention by tea polyphenols. Food and Chemical Toxicology, v.40, p.1145-1154, 2002.

Received on January 12, 2005 and accepted on August 30, 2006 